\title{
Covid-19 Salgınında Türkiye'de Yaşlılara Yönelik Uygulamalar ve Hizmetlerin Değerlendirilmesi
}

\author{
DOI: 10.26466/opus.858337
}

$*$

\author{
Aykut Can Demirel * - Semih Sütçü ** \\ * Öğr. Gör., Muğla Sıtkı Koçman Üniversitesi, Muğla Meslek Yüksekokulu, Muğla/Türkiye \\ E-Posta: aykutcandemirel@mu.edu.tr ORCID: 0000-0001-6388-7313 \\ ** Arş. Gör., Recep Tayyip Erdoğan Üniversitesi, İktisadi ve İdari Bilimler Fakültesi, Rize/ Türkiye \\ E-Posta: semih.sutcu@erdogan.edu.tr ORCID: 0000-0002-6833-3464
}

\begin{abstract}
Öz
İnsanlık ortaya çıktığı günden bugüne kadar savaşlar, göçler ve salgınlar gibi birçok felaketle karşılaşmıştır. Bu felaketlerden birisi de hiç şüphesiz Covid-19 salgınıdır. Çin'in Wuhan şehrinde ilk kez karşılaşılan bu yeni tür koronavirüs dünya genelinde milyonlarca kişiyi etkilemiş, bütün ülkelere yayılmış ve Dünya Sağllk Örgütü (DSÖ) tarafindan pandemi ilan edilmiştir. Bütün yaşlardaki insanlar için bu yeni tip virüsün bulaşma riski olmakla beraber yaşlılarda, yaşlılığa eşlik eden kronik hastalıklar nedeniyle ölüm oranları diğer yaş gruplarnna göre daha yüksektir. Yaşlllık döneminde bireyler diğer yaş gruplarına göre daha fazla fizyolojik, psikolojik, sosyal ve ekonomik sorunlar ile karşı karşıya olabilmektedirler. Yaşlılı̆̆ı çok boyutlu yapısı ve kendine özgü sorunları ile birleşen Covid-19 salgını, yaşlılara özel uygulamaların ve yeni yaklaşımların ortaya çıkmasını zorunlu hale getirmiştir. Bu sebeplerle salgının başından itibaren dünya genelinde hükümetler yaşlı gruba yönelik önlemler, kısıtlamalar ve yeni hizmet modelleri geliştirmişlerdir. Salgın sürecinde Türkiye'nin yaşlılara yönelik yaptığı çalışmaların ve hizmetlerin incelenmesi ve değerlendirilmesi, gelecekte yaşanabilecek yeni salgınlara hazırlıklı olmak için önem taşımaktadır. Bu nedenlerle çalışmanın amacı Covid-19 salgını süresince Türkiye'de yaşlılara yönelik uygulamalarn ve hizmetlerin incelenmesi ve değerlendirilmesidir. Araştırmada yaşlılara yönelik uygulamalar; hizmetler, kısıtlamalar, ekonomik destek, izin/ayricaliklar ve tibbi hizmetler boyutlarında ele alınmıştır. Sonuç olarak, ele alınan boyutlarda yaşlıların psiko-sosyal ve ekonomik açıdan desteklenmeye çalışıldığı anlaşılmıştır. Ancak hizmetlerin planl, çok boyutlu ve sürdürülebilir olmaması nedeniyle uygulamalarn istenilen düzeyde etkiyi yaratmadığ söylenebilmektedir. Bu bağlamda yaşlılara sunulan hizmetlerin yaşlının merkezde olduğu çok boyutlu ve çözüme yönelik olması gerekmektedir.
\end{abstract}

Anahtar Kelimeler: Covid-19, salgın, yaşlılar, yaşlılık dönemi 
ISSN:2528-9527

E-ISSN : 2528-9535

Yıl Year: 11

Cilt Volume: 17

Sayı Issue :Pandemi Özel Sayısı

Nisan April 2021

\title{
Evaluation of Applications and Services for the Elderly During the Covid-19 Outbreak in Turkey
}

\begin{abstract}
Humanity has been faced with many disasters such as wars, migrations and outbreak since the day it emerged. One of these disasters is undoubtedly Covid-19 outbreak. This new type of coronavirus, which was encountered for the first time in Wuhan, China, affected millions of people worldwide, spread to all countries and was declared an outbreak by the World Health Organization (WHO). Although there is a risk of transmission of this new type of virus for people of all ages, mortality rates in the elderly are higher than other age groups due to chronic diseases accompanying old age. In old age, individuals may face more physiological, psychological, social and economic problems than other age groups. Combining with the multi-dimensional structure of old age and its unique problems, the The Covid-19 outbreak has made the emergence of applications and new approaches specific to the elderly mandatory. For these reasons, since the beginning of the outbreak, governments around the world have developed measures, restrictions and new service models for the elderly group. In the Covid-19 outbreak, during work for elderly people in Turkey, and to determine whether services are what are important to be ready for a new outbreak in the future. It is shown as an example by WHO with the studies conducted by Turkey in the Covid-19 outbreak for the elderly. Examining and evaluating the work and services of Turkey for the elderly during the outbreak process is important to be prepared for new outbreaks that may occur in the future. For these reasons, the purpose of the study is to evaluate and examine practices for the elderly in Turkey during the Covid-19 outbreak. Applications for the elderly; services, restrictions, economic support, permission/ privileges and medical services has been examined in this research. As a result, it was understood that the elderly people were tried to be supported psycho-socially and economically in the dimensions discussed. However, it can be said that the applications do not create the desired level of impact because the services are not planned, multi-dimensional and sustainable. In this context, the services provided to the elderly should be multidimensional and solution oriented, with the elderly at the centre.
\end{abstract}

Keywords: Covid-19, outbreak, elders, older age 


\section{Giriş}

İnsanlık tarih boyunca bölgesel veya küresel düzeyde veba, kolera, grip, tüberküloz gibi birçok salgına tanıklık etmiştir. Bu salgınlar tarihin gidişatını ve insanlığın gelişimini etkilemiş dahası çok sayıda insanın hayatını kaybetmesine yol açarak bireylerin, toplumların travma yaşamalarına neden olmuşlardır. Bu salgilarından birisi de halen devam etmekte olan Covid -19 (Yeni Koronavirüs Hastalığı)' dur. İlk olarak Çin'in Wuhan Eyaleti'nde 2019 yılı Aralık ayının sonlarında solunum yolu belirtileri (ateş, öksürük, nefes darlığı) gelişen bir grup hastada yapılan araştırmalar sonucunda 13 Ocak 2020'de tanımlanan bir virüstür (Huang ve diğerleri, 2020; Halk Sağlığ1 Genel Müdürlüğü, 2020a). Daha sonra bu yeni tip koronavirüs Çin dışına sırasıyla Tayland, Güney Kore, Amerika Birleşik Devletleri, İtalya ve Rusya'da görülmüştür (Euronews, 2020). Türkiye'de ilk vaka 11 Mart 2020 tarihinde görülmüş ve Dünya Sağlık Örgütü (DSÖ) de aynı tarihte bu durumu pandemi ilan etmiştir (T.C. Sağlık Bakanlığı, 2020a). Covid-19 salgını başladığı günden 19 Mart 2021 tarihine kadar virüsün dünya genelinde 121.464 .666 kişiye bulaşttğ 1 ve 2.684.093 kişinin ölümüne neden olduğu bildirilmiştir (WHO, 2021). Covid19 salgının Türkiye'de ilk vakanın görüldüğü tarihten 19 Mart 2021 tarihine kadar toplam vaka 2.971.633 kişiye ulaşmış ve 29.864 kişinin ölümüne yol açmıştır (T.C. Sağlık Bakanlığı, 2021c).

Covid-19 salgını psikolojik, sosyal ve ekonomik açıdan bütün dünyayı etkilemiş ve halen etkilemeye devam etmektedir. Salgında toplumların hemen hemen bütün nüfus grupları etkilenmiş olmasına karşın belirli bir yaşın üzerinde olan kişiler hastalığı daha ağır geçirmiş (Altın, 2020) veya bu hastalık nedeniyle yaşamlarını kaybetmişlerdir. Türkiye' de Covid-19 nedeniyle gerçekleşen ölümlerin \%43,51'i 65 ve üstü yaş grubundaki kişiler olduğu bildirilmiştir (T.C. Sağlık Bakanlığı, 2020b). Yaşlıların Covid-19'u daha ağır yaşamaları ve ölüm ihtimalinin yüksek olması nedeniyle birçok ülkede sokağa çıkma kısıtlamaları, dışarıda maske takma zorunluluğu, huzurevlerinde vardiyalı çalışma ve ziyaretçi yasağı/kıstllaması gibi tedbirler alınmaya başlanmıştır. Bu çalışmalara ilk başlayan ülkelerden birinin de Türkiye olduğu söylenebilir (Türk, 2020).

Salgın kapsamında yaşlı nüfus yoğun olarak etkilense de önlemler, kısıtlamalar ve yasaklar ile bütün insanlar için adeta bütün faaliyetlerin sınırlandırıldığı ve izole edilmiş bu yeni yaşam biçiminden kurtulmak için çalışmalar 
daha önce görülmediği kadar hızlandırılmıştır. Bu kapsamda salgının ivedilikle sonlandırılması ve normal hayata dönüş için birçok ülkede aşı çalışmaları yapılmaya başlanmıştır. DSÖ (29 Aralık 2020)'ye göre Dünya genelinde Covid-19 salgını için 232 aşı çalışması bulunmaktadır. Bu çalışmaların 172'si klinik öncesi 60' 1 ise klinik aşamasındadır (WHO, 2020b). Aşı çalışmalarının bazıları (Pfizer-BioNTech ${ }^{1}$, Sinovac, Moderna) 2020'nin Aralık ayı itibariyle toplu kullanım için bazı ülkelerden onay almıştır (The New York Times, 2020). 2021 yılının ilk aylarında birçok ülke Covid-19 salgınını sonlandırmak için toplu aşılamaya başlamıştır. Türkiye'de Sinovac Şirketinin Coronavac aşısı 13 Ocak 2021 tarihinde "Acil Kullanım Onayı" verilmiştir (TRT Haber, 2021) ve Türkiye'de ilk aşılama 13 Ocak 2021 tarihinde Sağlık Bakanı Dr. Fahrettin KOCA'nın aşılanması ile başlamıştır (T.C. Sağlık Bakanlığı, 2021a). Aşılar birer birer onay alıp uygulanmaya başlanmış olsa da maalesef dünya nüfusunun aşılanmasının uzun zaman alacağ 1 ve salgının en iyi ihtimalle 2021 yılının sonlarına doğru bitebileceği belirtilmektedir (Charumilind ve diğerleri, 2020; Powell, 2020).

Bu salgının yakın bir zamanda biteceğine dair umutlar aşıların başarıya ulaşmasıyla birlikte filizlenmiş olsa da tarih bize gelecekte yeni salgınların olabileceğini göstermektedir. DSÖ Başkanı Tedros Adhanom Ghebreyesus (2020) Salgın Hazırlık Gününde yaptı̆̆ konuşmada bu salgının son olmadığını; insanlar, hayvanlar ve dünya arasındaki ilişkinin iyileştirmeden ve iklim değişikliği ile mücadele edilmeden yeni salgınların ortaya çıkabileceğini ve salgınları bitirmede başarıya ulaşamayacağını hatırlatmıştır (UN News, 2020).

BM (2019) verilerine göre dünya nüfusunun $\% 9^{\prime}$ u 65 yaş ve üzerindedir. Benzer şekilde Türkiye'de yaşlıların toplam nüfusa oranı \%9,1'dir (TÜiK, 2020). Son 100 yılda yaşlı nüfusun hem dünya genelinde hem de Türkiye'deki artışı yaşlıların sorun ve ihtiyaçları için yeni çözümleri beraberinde getirmiştir. Ancak Covid-19'u yaşlılarda yıkıcı etkisi bu çözümlerin yetersiz kalmasına yol açmıştır. Yaşlı nüfusun artışı ve Covid-19 salgının en çok yaşlılarda ölümlere neden olması hem Türkiye' de hem de birçok ülkede yaşlılara özgü tedbir, kısıtlama ve yasakların olmasına aynı zamanda bugüne kadar yapılmamış yeni hizmet modellerinin doğmasına ortam sağlamıştır.

\footnotetext{
${ }^{1}$ Pfizer-BioNTech'in aşası 01.01.2021 tarihinde acil durumlar için DSÖ'den onay almıştır (Reuters, 2021).
} 
Covid-19 salgını insanlığın karşılaştığı ilk salgını değildir. Geçmişten günümüze salgınların varlığı ve yıkıcılığı göz önüne alındığında sonuncusu da olmayacaktır. Covid-19 salgınında yapılan mücadele, özellikle de yaşlılara yönelik çalışmalar gelecek salgınlara hazırlık ve müdahale için önem taşımaktadır. Bu nedenlerle, çalışmanın temel amacı Covid-19 salgınında Türkiye'de yaşllara yönelik uygulamalar ve hizmetlerin incelenmesi ve değerlendirilmesidir. Çalışmanın temel amacı doğrultusunda alt amaçlar belirlenmiştir. Alt amaçlar sırasıyla şu şekilde soru cümlesi olarak ifade edilmiştir:

1- Türkiye' de Covid-19 Salgını süresince yaşlılara yönelik uygulamalar nelerdir?

2- Türkiye'de Covid-19 salgınında yaşlılara yönelik uygulamalara; "Hizmetler, Kısıtlamalar, Ekonomik Destek, İzinler ve Ayrıcalıklar, Tibbi Hizmetler" boyutunda nasıl değerlendirilebilir?

Çalışmanın amaçları doğrultusunda Türkiye'de Covid-19 salgını sürecinde yaşlılara yönelik yapılan uygulamaların incelenmesi ve değerlendirilmesi gelecekte yaşanabilecek muhtemel salgınlar için de bir yol gösterici olacaktır.

\section{Covid-19 Salginı}

Koronavirüsler insan, yarasa, domuz, kedi, köpek, kemirgen ve kanatlılarda bulunabilmektedir. İnsanlarda soğuk algınlığından zatürreye kadar değişen solunum yolu enfeksiyonlarına neden olmaktadırlar. Özellikle zoonotik (hayvanlardan insanlara geçen hastalıklar) hastalıklarda yüksek ateş, öksürük, kas ağrısı, diyare, nefes darlı̆̆ı şeklinde semptomlar olabilmektedir (Tatar ve Adar, 2020). Koronoavirüsler ilk kez bir salgına neden olmamıştır. Daha önce de Ortadoğu Solunum Sendromu (MERS) ve Şiddetli Akut Solunum Sendromu (SARS) gibi salgınlara neden olduğu bilinmektedir (T.C. Sağlık Bakanlığı, 2020c).

SARS, koronavirüsün neden olduğu bir solunum yolu hastalığıdır. Damlacık yolu ile insandan insana bulaşır. Kasım 2002-Haziran 2003 yılları arasında süren salgın Hong Kong'da başlamıştır. SARS salgını sırasında dünya çapında 8.422 vaka ve 916 ölüm görülmüş̧ür. SARS salgınında \%50 oranında 65 yaş ve üzerini etkilemiştir (Parlddar, 2020). MERS insandan insana yakın temas yolu ile yayılan ve ateş, öksürük ve nefes darlığ 1 ile belirti veren tüm yaşlarda görülebilir. İlk olarak Eylül 2012' de Suudi Arabistan' dan bildirilmiş, 
ancak retrospektif araştırmalar sonucunda, bilinen ilk olguların Nisan 2012' de Ürdün'de meydana geldiği saptanmıştır (Parıldar, 2020).

Her ne kadar koronavirüsler daha önce de SARS ve MERS gibi salgınlara neden olsa da Covid-19 salgını boyutunda bir yayılım göstermemiştir. Covid19 salgını dünya üzerinde bütün ülkelere yayılmış olması, milyonlarca insanı enfekte etmiş ve neredeyse 2 milyona yakın kişinin ölümüne yol açması nedeniyle küresel bir sorun haline gelmiştir. Bu yıkıcı salgın sadece tıp bilimini ilgilendiren bir olgu olmaktan çıarak sosyal hizmet, psikoloji, ekonomi, felsefe, din gibi birçok disiplinin konusu haline gelmiştir.

Covid-19 insandan insana damlacık, temas ve bazı durumlarda aerosol (havada asılı kalma) yoluyla bulaşan ciddi akut solunum yolu enfeksiyonlarına sebep olan ölümcül bir hastalıktır (Halk Sağlığı Genel Müdürlüğü, 2020b; Zhou ve diğerleri, 2020; Parıldar, 2020). Covid-19 bulaştığ1 vakalarda çoğunlukla ateş, kuru öksürük ve yorgunluk semptomları gelişmekte ve sıklıkla da tat ve koku kaybı, burun tıkanıklığı, konjonktivit, boğaz ağrısı, baş ağrısı, kas ve eklem ağrısı, farklı cilt dökülmeleri, mide bulantısı, ishal ve titreme gibi semptomlarında da görülebildiği bilinmektedir (WHO, 2020a). Vakaların çoğu (yaklaşık \%80) hastanede tedaviye ihtiyacı duymayan iyileşmekte ve yaklaşık \%15'i ciddi bir şekilde hastalanarak oksijene ihtiyaç duymaktadır. Maalesef vakaların $\% 5^{\prime} \mathrm{i}$ ise kritik bir durumda hastalanmakta ve yoğun bakıma ihtiyaç duymaktadır (WHO, 2020a).

Covid-19'un seyri kişiden kişiye farklılık gösterse de 60 yaş ve üstü kişiler ve yüksek tansiyon, kalp ve akciğer sorunları, diyabet, obezite ya da kanser gibi altta yatan tıbbi sorunları olanların daha fazla risk altında olduğunu söylemek mümkündür (WHO, 2020a). Covid-19'un yaşlılarda çok daha ağır bir tablo sergilemesi yaşlılara dönük yeni hizmet modelleri geliştirilmesini de beraberinde getirmiştir.

Covid-19 ister enfekte olsun ister olmasin bireyleri aileleri ve toplumu psiko-sosyal açıdan etkilemektedir. Zorunlu karantinalar, sokağa çıkma kısıtlamaları, haber akışlarında sürekli olarak güncellenen vaka ve vefat sayıları, hastalığın mutasyonu gibi bilgiler bireyler üzerinde stres, depresyon, akut panik atak, kaygı bozuklukları, obsesif davranışlar, istifçilik, yalnızlık, umutsuzluk, paranoya, ölüm korkusu ve travma sonrası stres bozukluğuna (PTSD) neden olabilmektedir (Aşkın ve diğerleri, 2020; Chen ve diğerleri, 
2020; Dubey ve diğerleri, 2020; Göksu ve Kumcağız, 2020; Karataş, 2020; Reger ve diğerleri, 2020; Saladino, Algeri ve Auriemma, 2020; Santini ve diğerleri, 2020; Wang ve diğerleri, 2020).

İnsanın en temel ihtiyaçlarından birisi olan sosyalleşme ihtiyacı Covid-19 nedeniyle engellenmiş ve öncelikler farklılaşmıştır (Tamer, 2020). Dahası Covid-19 salgınını önlemek için yapılan kısıtlamalar aile içi şiddet vakalarının sayıların artmasına; dezavantajlı grupta yer alan çocuk, kadın, yaşlı ve engellilerin daha fazla istismar/sömürü riski ile karşı karşıya kalmasına neden olmuştur (Ekici, 2020; Dubey ve diğerleri, 2020; Karataş, 2020). Birçok ülke Covid-19 salgınını önlemek için okullar online eğitime geçmiş, işyerleri kapatılarak evden çalışma yöntemi benimsenmiş, sosyal yaşamda kullanılan davranış kalıpları askıya alınmış, hijyen davranışları ve mesafe kuralı çok önemli hale gelmiştir (Karataş, 2020; Tamer, 2020). Kısa dönemde dahi birçok psikososyal ve ekonomik soruna yol açan Covid-19 salgının uzun vadede bu alanlara daha fazla etki edeceği tahmin edilmektedir (Karataş, 2020). Her ne kadar devletler önlemler alsalar da Covid-19 salgınının işsizliği arttıracağı, toplumsal eşitsizlikleri ve adaletsizlikleri arttıracağı, özellikle dezavantajlı grupları daha kırılgan hale getirebileceği öngörülmektedir (Altın, 2020; Karataş, 2020; Tamer, 2020).

\section{Yaşlılık Dönemi ve Yaşlı Sorunları}

Yaşlılığın tanımlanması güç bir kavramdır. Yaşlılık olgusu kültürden kültüre, toplumdan topluma, zamana ve coğrafyaya göre değişiklik göstermektedir (Sütçü ve Demirel, 2020). Yaşlılığın kesin bir tanımının olmamasında ekonomik koşullar, fizyolojik ve psikolojik faktörler gibi birçok değişken etkili olmaktadır (Kalınkara, 2014). Yaşlılığın bu çok boyutlu yapısı ilgilenilen özelliğine göre farklı tanımlamalar ile sonuçlanmıştr. Ancak ulusal ve uluslararası çalışmalarda genellikle DSÖ'nün referansı olan 65 yaş ve sonrası kişilerin için "yaşlı" olarak tanımlanmaktadır.

Bugün 65 yaş ve üstü nüfus 20. yüzyılın başındakine oranla 10 kat daha fazladır. Sağlık alanındaki gelişmeler, bulaşıcı hastalıkların kontrol altında alınması, doğum oranının düşmesi yaşlı nüfusun hem oransal hem de sayısal olarak artmasına neden olmuştur (Zastrow, 2016). Dünyada ve Türkiye'de 65 yaş ve üstü nüfus, diğer tüm yaş gruplarından daha hızlı artmaktadır. Birleşmiş Milletler (BM) göre 2050' de dünya genelinde her altı kişiden biri (\%16) 
65 yaşın üzerinde olacağı tahmin edilmektedir (United Nations, 2019). Türkiye'de yaşlı nüfus son beş yılda \%21,9 artarak toplam nüfus içerisindeki oranı 2019 'da $\% 9,1$ olmuştur. 2060'ta ise yaşlı nüfusun toplam nüfus içerisinde \%22,6 olacağ tahmin edilmektedir (TÜIK, 2020).

Yaşlı nüfusun artması daha önce fark edilmeyen ihtiyaç ve sorunların ortaya çıkmasına neden olmuştur. Yaşlıların temelde sağlık, psiko-sosyal, bakım, sosyal dışlanma, ayrımclık ve ekonomik sorunlar yaşadığı söylenebilir (Sütçü ve Demirel, 2020).

Yaşlanma ile organizmada birçok sağlık problemi gelişmektedir. Yapılan araştırmalar yaşlıların demans, alzheimer, idrar tutmada zorlanma, görme ve işitme bozuklukları, yetersiz beslendiklerini, yürüme bozuklukları yaşadıklarını, kemik erimesi, yürüme bozuklukları yaşadıklarını göstermektedir. İnancı ve Gökçe Kutsal (1997) yaşlılıkta sıklıkla karşılaşılan sağlık problemlerini kelimelerin İngilizce karşılıklarını temel alarak "Yaşlılığın Yedi I "sı adı verdikleri sinıflama şu şekildedir;

1. Intellectual failure (Bilişsel yetersizlik)

2. Immobility (Hareketsizlik)

3. Incontinence (İdrar-gaita tutamama)

4. Iatrojenik problems (Iyatrojenik Sorunlar)

5. Involvement of the families (Ailelerin katlımı)

6. Instability (Dengesizlik)

7. Insomnia (Uykusuzluk)

Yaşlanma ile yalnızca organizmanın fizyolojik özelliklerinde bir gerileme ya da kayıp meydana gelmemektedir. Yaşlanmayla sosyal statü ve rollerde, tutumlarda ve kişilikte değişimler olmakta dahası bu dönemde birey sosyal izolasyona maruz kalmakta ve yalnızlık hissini yaşamaktadır (Kourkouta, Iliadis ve Monios, 2015; Danış ve Günay, 2019). DSÖ (2017)'ye göre 60 yaş ve üzeri kişilerin \%20'sinden fazlası ruhsal problemler yaşamaktadır. Dünya genelinde yaşlılarda sıklıkla bunama, depresyon ve anksiyete bozuklukları görüldüğü bildirilmektedir (Kourkouta, Iliadis ve Monios, 2015; DSÖ, 2017).

Bakım; hayatî önem arz eden fizikî, psikolojik ve sosyal aktivitelerin ve fonksiyonların sağlanmasında, yeniden yerine getirilmesinde ve uyumunda bakıma muhtaç kişiye yardımcı olmaktır (Genç ve Barış, 2015). Bakım ihtiyacı hemen hemen her yaşta karşılaşılabilen bir durum olsa da yaşılılık dönemi ile fizyolojik ve psiko-sosyal boyutlarda yaşanan gerilemelerden dolayı yaşlılık sorunları arasında ele alınmaktadır (Sütçü ve Demirel, 2020). 
Sosyal dışlanma kavramı ayrımcılık ve ırkçılık ile bağlantılı bir olgudur (Kourkouta, Iliadis ve Monios, 2015). Sosyal dışlanma bireylerin toplumla bütünleşme ve fırsatlara erişimini engelleyen, temel ihtiyaçlardan ve vatandaşlık haklarından yoksun bırakan durumu tanımlar (Palmer, 2011). Sosyal dışlanma yoksulluk, işsizlik, ayrımclğa neden olabileceği gibi bunların bir sonucu da olabilir. Yaşlıların çeşitli nedenlerden dolayı eğitim, ekonomi, istihdam piyasası, komşuluk gibi sosyal ilişkilerde, sosyo-kültürel alanda, sağlık, politika ve katılım gibi alanlardan dışlandıkları yapılan araştırmalarda ortaya konulmuştur (Dylan, 2012; Walsh, Scharf ve Keating, 2017).

Yaşlıların yaşadığı sorunlarından birisi de yaş ayrımcılığıdır. Yaşlı ayrımcllığı negatif ve pozitif tutumları içerse de genellikle olumsuz anlamda kullanılmaktadır. Yaş ayrımcılığı kavramı ilk kez Butler (1969) tarafından kullanılmış olup (Sütçü ve Demirel, 2020) kimsenin asla kabul edemeyeceği "yaşlı akbaba, kart horoz, moruk, taşkafa" gibi kelimelerle dilimizde mevcuttur (Zastrow, 2016). Yaşlı ayrımcılığı bir kişiye sadece yaşı nedeniyle gösterilen farklı tavır, önyargı, davranış ve eylemleri içinde barındıran çok boyutlu bir terimdir (Vefikuluçay, 2008). Yaşlılara yönelik ayrımclık yaşlıların bağımlı ve bakıma muhtaç olarak algılanmasına, muhatap alınmamasına, sosyal hayattan dışlanmasına ve istismar edilme görünümlerine sahiptir (Buz, 2015). Sütçü ve Demirel (2020) yaşlıya yüklenen olumsuz anlamları şu şekilde belirtmişlerdir;

- Yaşlılık dönemi sürekli yetersizlik ve hastalıklar ile anılması

- Yaşlanma ile artan cinsel yetersizlik hali

- Zihinsel süreçlerde yavaşlama ile öğrenme güçlükleri

- Organizmanın yaşlanma ile dış görünümünün bozulması ve çirkinlik algısı

- İş hayatından uzaklaşma ile işe yaramazlık ve çevreye karşı artan bağımlılık

- Toplumdan kopma ve yalnızlık

- Yoksulluk

Ekonomik sorunlar sadece yaşlıların değil toplumda hemen hemen bütün nüfus gruplarının yaşayabileceği sorunlar arasında sayılabilir. Ancak yaşlılık döneminde işsiz kalma, emekli olma, sağlık harcamalarının artması, finansal okuryazarlığın düşük olması (Lusardi ve Mitchell, 2011) ve enflasyon (özellikle sabit gelire zarar vermekte) yaşlıların ekonomik sorunlar yaşamasına ve yoksullaşmasına neden olmaktadır (Zastrow, 2016). 
Yaşlılık döneminde ortaya çıkan sorunları anlamak için, yaşlılığı biyolojik, psiko-sosyal ve ekonomik perspektifte değerlendirmek gerekir. Yaşlılığın doğası gereği ve yaşamın son evresi olması bakımından birçok sorunu barındırdığ ifade edilebilir. Bu bağlamda yaşlılık temelinde araştırmaların arttığı ve çalışmalarda yaşlılık ile ilişkilendirilen sorunlara çokça yer verildiği görülmektedir. Yaşlılık ile ilgili kapsamlı bir çalışma yapan Şentürk (2018), yaşlılık dönemi sorunların fiziksel ve ruhsal sağlık problemleri, ihmal ve istismar, aktif çalışmadan ayrılma, yalnızlık ve sosyal izolasyon, bakım sorunları ve ölüm korkusu olarak ele almaktadır. Soysal (2020) ise yaptığı çalışmada yaşlılık dönemindeki en büyük sorun alanlarından birinin çalışma hayatı ve sosyal uyum olduğunu belirtmektedir.

Yaşlılık sorunlarını içsel ve dışsal sorunlar olarak iki farklı boyutta ele almak gerekmektedir. İçsel sorunlar daha çok yaşlıllğın doğal gelişim aşamasında ortaya çıkan, biyolojik, fiziksel ve sağlık sorunlarından oluşmaktayken, dışsal sorunlar daha çok toplum ya da toplumun bir kesimi tarafından yaşlılığa ve yaşıllara yönelik tutum davranışlardan ortaya çıkmaktadır. Bu bağlamda yaşlıların toplum içinde yaşadığı yalnızlık, dışlanma, ihmal ve istismar, yaş ve yaşlı ayrımcllığı, damgalanma gibi sorunların ortaya çıkması dışsal sorunlar olarak ele alınabilmektedir. Yaşlılar üzerinde hem içsel hem de dışsal sorunları tetikleyen, yaşlıların toplum içinde yalnızlık, dışlanma ve izolasyona karşı direncini kıran etkenlerden birisi de Covid-19 salgını olmuştur.

\section{Yaşlılar ve Covid-19 Salgını}

Covid-19 salgını dünya üzerinde milyonlarca insana bulaşmış ve çok sayıda kişinin hayatını kaybetmesine neden olmuştur. Covid-19 salgını bütün insanları etkilemekte ancak yaşlılar veya kronik rahatsızlığı olanlar için daha ciddi sonuçlar doğurmaktadır. Salgın başladığı andan itibaren ortaya konulan araştırmalar Covid-19'un yaşlllarda mortalitenin diğer yaş gruplarına oranla daha fazla olduğunu ortaya koymaktadır (T.C. Sağlık Bakanlığı, 2020b; WHO, 2020a; Zhou ve diğerleri, 2020).

Yaşlanma ile kişilerde çok çeşitli sağlık sorunları görülebilmektedir. Bu sağlık sorunları arasında enfeksiyonlar önemli bir yere sahiptir. Yaşlanmayla birlikte bağışıklık sisteminin işlevlerinden bozulmalar ortaya çıkar (Altın, 2020). Bu nedenle yaşlıların enfeksiyonlara karşı daha savunmasız hale geldiği söylenebilir. Altın (2020), yaşlılarda Covid-19'un daha ağır seyrettiğini 
ancak yaşlılar arasında da standart bir hastalık seyrinden bahsetmenin mümkün olmadığını; bütün yaşlıların benzer şekilde hastalığı ağır geçireceğini söylemenin mümkün olmadığını ifade etmektedir.

Salgından bağımsız olarak birçok sorunla karşı karşıya kalan yaşlılar, Covid-19 salgını birlikte sağlık temelinde sorunların ötesinde, yaşlıları psikososyal açıdan olumsuz etkileyen birçok sorunla da karşılaşmışlardır. Genel olarak yaşlılara yönelik, yaşlı ayrımcılığı ile toplumsal bütünleşme ve kabul noktasında sorunlar yaşamışlardır. Yaşlıların Covid-19 salgınında en zayıf nokta olarak tanımlanması, yaşlıların izolasyonu da beraberinde birçok sağlik, ekonomik ve psiko-sosyal sorunlara neden olmuştur.

Hastalığın yaşlılarda daha ağır bir tablo göstermesi yaşlılara dönük önlemleri, kısıtlamaları/sokağa çıkma yasağı gibi uygulamalara beraberinde getirmiştir. Ancak bir yandan alınan bu "önlemler" yaşlı ayrımcılığını daha görünür k1lmıştır (Çobanoğlu, 2020; Türk, 2020; Altın,2020. Yaşlı bireylerin enfekte olmasına yönelik tedbirler ilk başta sosyal medyada eğlence konusu haline getirilmiş ve bu tutum ve davranışlar daha sonra yerini yaşlılara yönelmiş zorbalığa ve nefret söylemine bırakmıştır (Türk, 2020). Uysal ve Eren (2020) Covid-19 salgınında yaşlı ayrımcılığı konusunda twitter söylemleri üzerinden yaptıkları çalışmada; "alay etme, küçümseme, aşağılama, hakaret etme ve nefret söylemleri gibi yaşa dayal ayrımcı tutum, söylemler" tespit etmişlerdir.

Yaşlı bireylerin salgına karşı izole edilmesi depresyon, anksiyete düzeylerinin yükselmesine, öfke, korku ve yalnızlık duyguların hissetmelerine neden olmuştur (Santini ve diğerleri, 2020; Sattari ve Billore, 2020; Uysal ve Eren, 2020). Wang ve diğerleri (2020) salgın sürecinde yaşlıların daha stresli, ajite ve aşırı şüpheci olduklarını belirtmişlerdir. Yaşlıların Covid-19 salg1nında psiko-sosyal sorunları ile ilgili yapılan bir diğer çalışmada yaşlıların izolasyon döneminde anksiyete, depresyon, kötü uyku kalitesi ve fiziksel hareketsizlik sorunları yaşadığı tespit edilmiştir. (Sepúlveda-Loyola ve diğerleri, 2020)

Yaşlılık döneminde emeklilikten veya yaş ayrımcılığı nedeniyle oluşan işsizlik nedeniyle gelirde kayıplar yaşanmaktadır. Düşük gelire sahip olmak sağlıklı beslenememeye, iyi bir konutta yaşayamamaya ve sağlık hizmetlerinden yararlanamamaya neden olabilir. Bu açıdan düşünüldüğünde yaşllar için Covid-19 sadece bir hastalık ya da sağlık sorunu değil aynı zamanda yaşlının sosyal yaşamını altüst edebilecek bir olgu olarak ifade edilebilir. 


\section{Türkiye' de Covid-19 Sürecinde Yaşlılara Yönelik Uygulamalar ve Hizmetler}

Covid-19 yaşlı bireyler üzerinde yıkıcı etkilere sahip bir hastalıktır. Yaşlı nüfusun hem dünya genelinde hem de Türkiye'deki oranı göz önünde alınd1ğında yaşlıları Covid-19'dan korumaya yönelik uygulamalara ağırlık verilmesi beklenen bir durum olarak karşımıza çıkmaktadır. Türkiye' de Covid-19 salgınında yaşlılara yönelik uygulama ve hizmetleri beş farklı kategori içerisinde değerlendirilebilir. Bu kategoriler; ilk olarak riskli grup olarak yaşlıların izolasyonuna yönelik "kısıtlamalar", ikincisi, kısıtlamalara bağlı olarak sunulan "hizmetler", üçüncüsü salgın ile hem sağlık hem temel ihtiyaçlara yönelik harcamaların artması ile "ekonomik destek" ve dördüncüsü yaşlıların fizyolojik, psikolojik, duygusal ve sosyal ihtiyaçlarına yönelik, "izinler ve ayricalıklar" ve sonuncusu tedavi ve aşılamaya yönelik "tıbbi hizmetler" olarak siralanabilir.

\section{Yaşlılara yönelik hizmetler}

Türkiye Çin' de salgının çıktığı ilk andan itibaren hem nüfusun geneli hem de yaşlı bireylerin sağlıkları için Covid-19 ile mücadele çalışmalarını başlatmıştır. Salgınla ilgili ilk çalışmanın Aile, Çalışma ve Sosyal Hizmetler Bakanlığı (AÇSHB) tarafından 7 Ocak 2020'de Covid-19 ile ilgili 81 İl Müdürlüğüne gönderilmiş resmi yazı olduğu söylenebilir. Bu yazıyla önleyici tedbirler alınarak salgın sürecinde hızlı ve etkin bir şekilde mücadele edebilmek için ' $T a$ kip ve İzleme Birimi' oluşturulmuştur (Türk, 2020). Ayrıca kuruluşlara yeni kabul ve kuruluş dışına çıkışı yasaklayarak bulaş durumu önlenmiş, olası risklere karşı kuruluşlarda 'izolasyon odaları' ve huzurevlerinden bağımsız olarak 'izolasyon kuruluşları' oluşturulmuştur (Türk, 2020).

AÇSHB' nın yazısından üç gün sonra 10 Ocak 2020 tarihinde Sağlık Bakanlığ1 tarafından Koronovirüs Bilim Kurulu oluşturulmuştur. 11 Mart 2020 Sağlık Bakanlığı Halk Sağlığı Genel Müdürlüğü tarafından Bilim Kurulu'nun çalışması olarak COVID-19 Rehberi yayınlanmıştır (Erdem, 2020).

AÇSHB, Covid-19 salgını boyunca yatılı kuruluşlara yönelik rehberler hazırlamıştır. İlk olarak, kuruluşlarda Covid-19 salgınına yönelik Mart 2020'de “Kuruluşlarımıza Yönelik Koronavirüs Bilgilendirme Rehberi-1"'i hazırlamış ve kuruluşlarda hastalık tanı ve teşhisine yönelik bilgilere yer verilmiştir. Ay- 
rıca rehberde asgari düzeyde önlemlere yer verilmiştir. İlk rehberin yayınlanmasından sonra "Kuruluşlarımıza Yönelik Koronavirüs Bilgilendirme Rehberi-II" hazırlanmış ve rehberde Covid-19 salgınına yönelik kurum bazında alınan önlemler ayrıntılı olarak ele alınmış ve sonrasında kuruluşlara yönelik tedbirler şu başlıklar altında ayrıntılı olarak açılanmıştır;

- İdari tedbirlerde izolasyona yönelik düzenlemeler, nöbetler, 14 günlük vardiya sistemi, personelin yıllık izinlerinin kısıtlanması ve yaşlıların tek kişilik odalarda kalması için çalışmalar ele alınmıştır.

- Kuruluşlarda kalanlara yönelik tedbirler bağlamında, sürekli maske takmaya özen gösterilmesi, kuruluşlara giriş çıkışların sınırlandırılması ve kısıtlanması, tıbbi tedavi gibi durumlarda yaşlıların tekrar kuruluşa kabul için doktor raporu istenmesi, kurum dışına çıkış ve girişlerde izolasyon kuruluşlarının kullanılması, Covid-19 teşhisinde, şüphesinde veya temaslı olma durumuyla karşılaşmasında yapılması gerekenler ayrıntılı olarak açıklanmıştır.

- Çalışanlara yönelik tedbirlerde kuruluşta hijyen kuralları, giriş çıkışa yönelik düzenlemeler, Covid-19 tanısı, şüphesi ya da temaslısı olunması durumunda yapılması gerekenler ayrıntılı ele alınmış ve çalışanların psikososyal boyutta desteklenmesi ifade edilmiştir (AÇSHB, 2020a).

AÇSHB (2020c), Engelli ve Yaşlı Hizmetleri Müdürlügü̈, Haziran, 2020' de “Kuruluşlarımıza Yönelik Covid-19 Normalleşme Rehberi-I"'i yayınladıktan sonra, vaka sayılarındaki azalma eğilimi ile bir normalleşme sürecine girilmiştir. Normalleşme ile kuruluşlarda kısıtlamalar belli şartlar doğrultusunda esnetilmiştir. Bu bağlamda, kuruluşlara izolasyon kuralları ile kabullerin yapılması, yakın akraba ziyaretlerine izin verilmesi, sportif ve sosyal faaliyetlerin düzenlenmesi gibi konular ele alınmıştır. 2020 yılının sonlarında vaka sayılarındaki hızlı artış ile, ikinci dalga olarak ifade edilen yeni bir sürece girilmiştir. Bu yeni süreç kısıtlamaları ve önlemleri yeniden gündeme taşımıştır.

İçişleri Bakanlığının 22 Mart 2020 tarihinde "65 yaş ve Üstü ile Kronik Rahatsızlığı Olanlara Sokağa Çıkma Yasağı” isimli genelge ile tek başına yaşayan ve ihtiyaçlarını karşılayacak yakını bulunmayan 65 yaş ve üstü kişilerin temel ihtiyaçlarını karşılamak amacıyla Vali/Kaymakamların başkanlığında Vefa Sosyal Destek Grupları oluşturulmuştur (T.C. İçişleri Bakanlığı, 2020a). 65 
yaş ve üstü bireylerin ikametlerinden ayrılmadan ihtiyaçlarını karşılayabilmeleri için 112, 155 ve 156 mobil numaraları üzerinden ihtiyaçlarını bildirmeleri kararlaştırılmıştır (T.C. İçişleri Bakanlığı, 2020a). Vefa Sosyal Destek Grupları polis, jandarma, bekçi, zabıta, öğretmen, AFAD personeli gibi kamu çalışanlarının yanında sivil toplum kuruluşu gönüllülerinden meydana gelmiştir (Duran , 2020). Salgının toplumsal düzeyde büyük çaplı etkisi sonucu dezavantajlı kesime destek sağlamak ve özellikle yaşlıların ve kronik hastalığ olanların ihtiyaçlarını karşılamak için oluşturulmuş bu destek mekanizması profesyonel meslek elemanlarının yanında gönüllülerin de hizmet vermesi ile kapsayıcılık ve ulaşılabilirlik açısından olumlu bir etki yarattığı söylenebilir. Ancak, Vefa Sosyal Destek grupları içerisinde yer alan kişilere yapılandırılmış ve sistematik bir eğitim verilmemesi ise profesyonel uygulamada yetersizliklerin oluşabileceğinin bir göstergesidir. Vefa Sosyal Destek Grupları 14 Mayıs 2020 tarihi itibariyle 6.649.461 haneye ulaşmıştır. Bu kapsamda emekli maaşından gıdaya, ilaçtan hijyen malzemelerine kadar teminini sağlamışlardır (T.C. İçişleri Bakanlığı, 2020c). Ülke nüfusu göz önüne alınd1ğında Vefa Sosyal Destek Gruplarının ilk aşamada kısa sürede çok fazla yaşlı bireye ulaştı̆̆ı ve faydalı olduğu söylenebilir ancak salgının uzun bir süreye yayılması ile etkinliğinin azaldığı söylenebilir.

\section{Yaşlılara yönelik kısıtlamalar}

Ilk Covid-19 vakanın tespit edilmesi ve salgının yayılması ile tedbirler arttırılmıştır. Bilim Kurulunun önerileri doğrultusunda bireysel alışkanlıkları ve toplumsal yaşamı etkileyen türden birçok tedbir ve yasaklar aşamalı olarak hayata geçirilmiştir (Gencer, 2020). Türkiye' de ilk Covid-19 vakası görülmeden önce komşu ülkelerde (Irak, İran, Bulgaristan, Yunanistan) vakaların bildirilmesi ile bu ülkelere seyahat kısıtlamaları getirilmiştir (BBC, 2020).

İçişleri Bakanlığının 22 Mart 2020 tarihinde "65 yaş ve Üstü ile Kronik Rahatsızlığı Olanlara Sokağa Çıkma Yasağı” 81 il Valiliğine gönderdiği genelgeyle 65 yaş ve üzeri bağışıklık sistemi düşük ve kronik akciğer hastalığı, astım, $\mathrm{KOAH}$, kalp/damar hastalığı, böbrek, hipertansiyon ve karaciğer hastalığı olanlar ile bağısııklık sistemini bozan ilaçları kullananların ikametlerinden dışarı çıkmaları, açık alanlarda, parklarda dolaşmaları ve toplu ulaşım araçları ile seyahat etmeleri yasaklanmıştır (T.C. İçişleri Bakanlığı, 2020a). 
AÇSHB salgın süresince Covid-19'a karşı birinci derecede risk grubunda bulunan, kurum bakımında olsun ya da olmasın bütün engelli ve yaşlı bireylerin korunmasına yönelik çalışmalar yapmıştır (Ekici, 2020). Bunun için vaka yönetimi, personel risk yönetimi ve acil durum risk yönetimi planları yapılarak ve uygulamaya konarak, hizmet alanlarla beraber, hizmet verenlerin de sağlıkları ve güvenlikleri garanti altına alınmış, hizmetin kaliteli ve kesintisiz sunumu sağlanmıştır (AÇSHB, 2020a). AÇSHB'ye bağlı 426 Huzurevi ve Yaşlı Rehabilitasyon Merkezinde 27500 yaşlı bakım ve sağlık hizmeti almaktadır. Bu kuruluşlarda kalan yaşlıları Covid-19 salgınından korumak için 26 Mart 2020 tarihinde vardiya sistemine geçilmiştir. Bu kurumlardaki görevliler 14 günlük vardiyalar şeklinde çalı̧maya başlamışlardır (AÇSHB, 2020a)

\section{Yaşlılara yönelik ekonomik destek hizmetleri}

Salgın nedeniyle 65 yaş ve üstü ve kronik rahatsızlığı nedeniyle sokağa çıkamayacak/kısıtlamada olan vergi mükellefi kişiler beyanname ve ödemleri yasak bitene kadar ertelenmiştir. Maaşını kamu bankalarından alan emeklilerin istedikleri takdirde maaşlarını evden alabilmeleri sağlanmıştır. Dahası bakım merkezlerinden faydalanmak isteyen yaşlıların gelir ölçütüne bakılmaksızın kurum bakımı alabilmeleri sağlanmıştır (Engelli ve Yaşlı Hizmetleri Genel Müdürlüğü, 2020). Emekli maaşında en düşük miktar 1000 TL'den 1500 TL'ye yükseltilmiştir. Emekli bayram ikramiyesi Nisan ayında ödenmiştir. Emekli maaş promosyon ödemelerinin de doğrudan hesaplara yatırılması kararı alınmıştır (Durmuş ve Şahin, 2020).

\section{Yaşlılara yönelik izin ve ayrucalıklar}

Yaşlılara yönelik ilk aşamada uygulanan ayrıcalıkların çoğu şartlı ayrıcalıklar olarak ele alınmıştır. 22 Mart 2020 tarihinde yaşlılara ve kronik rahatsızlığı olanlara sokağa çıkma yasağı getirilirken; organ ve kemik iliği nakli olanlar, immun (bağışıklık) yetmezliği olanlar ve böbrek yetmezliği nedeniyle diyalize giren hastalar bu kısıtlamadan muaf tutulmuşlardır (T.C. İçişleri Bakanlığı, 2020a).

Kronik hastalığa sahip olanlar ve 65 yaş ve üstü kişiler için sokağa çıkma kısıtlaması Bilim Kurulunun tavsiyesi, kamuoyundan gelen talep ve bireylerin psikolojik iyilikleri için esnetilmiştir. Esnetme ile kısıtlamaya tabi kişiler haftanın belli günleri ve belli saatleri ikametlerinden dışarı çıkabilmişlerdir. 
Örneğin 6 Mayıs 2020 tarihinde İçişleri Bakanlığının kararıyla 10 Mayıs 2020 Pazar günü 11:00 - 15:00 saatleri arasında 65 yaş ve üzeri yaşlılara yürüme mesafesiyle sınırlı olarak koronavirüs kurallarına uyarak dışarı çıkmalarına izin verilmiştir (T.C. İçişleri Bakanlığı, 2020b).

Vaka sayılarındaki düşüş ile 1 Temmuz 2020 tarihinde yeni normal yaşam sürecine girilmiş yasaklar ve kısıtlamalar nedeniyle kapalı olan birçok işletme yeniden açılmıştır (Hürriyet Gazetesi, 2020a). Yeni normal yaşam sadece Türkiye'de değil bütün dünyada maalesef umulduğu gibi olmamış insanlar Covid-19 salgınından önceki normallerine göre yaşamaya devam etmişler ve bu durum vaka sayılarının katlanarak artmasına ve salgında ikinci dalgaya neden olmuştur. 2020 yılı Kasım ve Aralık aylarında vaka sayılarının 30 bin ve üzerine çıkmasıyla beraber normalleşme yerini yeni önlemlere bırakmıştır. 01 Aralık 2020 tarihinde İçişleri Bakanlığının genelgesiyle hafta sonları bütün saatlerde ve hafta içi 21:00-05:00 saatleri arasında sokağa çıkma yasağı getirilmiştir. Kısttlamanın olduğu Cumartesi ve Pazar günlerinde market, bakkal, manav gibi işletmeler 10:00-17:00 saatlerinde hizmet verebilmeleri, vatandaşların (65 yaş ve üzeri ile 20 yaş altı hariç) zorunlu ihtiyaçlarını karşılayabilmeleri için araç kullanmadan ikametine en yakın market, bakkal vb. gidip gelmelerine izin verilmesi kararlaştırılmıştır. Sokağa çıkma kısıtlamasının olduğu gün ve saatlerde 65 yaş ve üstü bireyler unutulmamış ve temel ihtiyaçların Vefa Sosyal Destek Birimleri ile karşılanması kararlaştırılmıştır (T.C. İçişleri Bakanlığı, 2020d).

\section{Yaşlılara Yönelik Tıbbi Hizmetler}

Covid-19 salgınında Türkiye' de yaşlıların tıbbi hizmetlerden yararlanması en etkin şekilde uygulanmaya çalışılmıştır. Yaşlılara yönelik bu tıbbi hizmetleri 2 boyutta ele almak mümkündür. Bunlardan birincisi tele-tıp² uygulamaları ve ikincisi ise aşılama çalışmalarıdır.

Bilişim teknolojisindeki gelişmeler Covid-19 salgını süresince insanlığa önemli bir avantaj sağlamıştır. Covid-19 salgının getirdiği zorunluluklar nedeniyle başta sağlık ve eğitim olmak üzere birçok hizmet, çevrimiçi araçlar ile sağlanmaya başlanmıştır. Sağlık alanında çevrimiçi araçların kullanımı

\footnotetext{
2 Bireylerin ve toplumların sağlık düzeylerinin iyileştirilmesi, hastalıkların ve kazaların önlenmesi; sağlık personelinin sürekli eğitimi ile tüm sağlık profesyonelleri tarafından bilgi ve iletişim teknolojileri kullanılarak, uzaktan ve geçerli bilgi iletişim yöntemleri ile sağlık hizmetlerinin verilmesidir (DSÖ, 2010).
} 
her ne kadar Covid-19 salgınında önemli hale gelmiş olsa da Türkiye için yeni değildir. Türkiye'de ilk kez 2006 yılında "Bilgi Toplumu Stratejisi" ile "Bilgi Toplumu Stratejisi Eylem Planın"da tele-tıp uygulamaları hayata geçirilmiştir (Uyanusta Küçük, 2020). Covid-19 salgınında Türkiye'de tele-tıp uygulamaları kapsamında yaşlılara yönelik olarak canlı doktor görüşmesi (Çapacı ve Özkaya, 2020), tahlil sonuçları, radyoloji sonuçlarını görüntüleme sağlanmış, diyet listeleri düzenlenmiş, Covid-19 salgını için bilgilendirme yapılmış dahası kronik rahatsızlığı bulunanların raporlu ilaçların reçete zorunluluğu kaldırılmıştır (AÇSHB, 2020b). Ayrıca tıbbi tedavi ve müdahale gerektiren durumlarda yaşlıların sağlık kuruluşlarına randevu sistemi ile kabul edilerek, günün belirli saatleri yaşlılar için ayrılmıştır.

Yaşlı nüfusta diğer yaş gruplarına göre kanser vakalarının yüksek olması Covid-19 risk faktörü ile birleştiğinde onkolojik tedaviler ve palyatif bakım konusunu daha da önemli hale getirmiştir (Yazar, 2020). Covid-19 salgınında kanserli hastaların takipleri, tedavi süreçlerinin kontrolü, semptomlarının yönetimi ve psiko-sosyal yönden desteklenmeleri tele-tıp uygulamaları ile gerçekleştirilmiştir (Tanrıverdi, 2020). Covid-19 salgınında yüksek risk altındaki bir diğer grup da diyalize giren yaşlı hastalardır. Sağlık Bakanlığı 16.04.2020 tarihinde diyaliz merkezleri için tedbirler için öneriler sunmuştur. Bu kapsamda diyaliz merkezine gelen hastaların mümkün olduğunca toplu taşımayı kullanmamaları hastanın en az süre bekleyecek şekilde randevuların düzenlenmesi, hastanın maske ile tedaviye gelmesi ve ev diyalizi alan hastalara mümkün olabildiğince telefon, bilgisayar gibi elektronik sistemler kullanarak hastaneye gelmelerine ihtiyaç duymadan evde klinik bakım hizmeti verilmesi ve gerekli görüldüğünde evde bakım hizmeti verilmesi, diyaliz merkezlerinin hasta servis araçlarında yolcu sayısının sosyal mesafe kurallarına göre düzenlenmesi gerektiği önerilmiştir (Anadolu Ajansı, 2020).

Covid -19 salgınında yaşlılara yönelik tıbbi hizmetlerde diğer önemli boyut aşılama çalışmalarıdır. Türkiye Çin'de bulunan Sinovac şirketinin Coronavac aşısı için anlaşma gerçekleştirmiştir. 11 Şubat 2021 tarihine kadar Türkiye bu aşıdan 15 milyon doz temin etmiştir (TRT Haber, 2021). Türkiye'de aşılamanın ne zaman tamamlanacağına dair tarih tam olarak bilinmese de aşılama programı için önceliklere göre dört grup oluşturulmuştur (T.C. Sağlık Bakanlığı, 2021b). Birinci grupta birçok ülkede olduğu gibi Türkiye'de de sağlık çalışanları ve yaşlılar bulunmaktadır. Bu kapsamda birinci grupta yer alan sağlık çalışanları ile huzurevi, bakım merkezinde kalan kişiler ve 90 yaş 
üstü vatandaşlar aşılanmaya başlamıştır (Anadolu Ajansı, 2021). 90 yaş ve üstü kişilerin aşılanması tamamlandıktan sonra sırasıyla 85 yaş, 75 yaş, 70 yaş ve 65 yaş ve üstü kişilerin aşılanmasına geçilmiştir (TRT Haber, 2021).

Coronavac aşısı 2 doz şeklinde ücretsiz olarak uygulanmaktadır. Türkiye' de 14.02.2021 tarihine kadar T.C. Sağlık Bakanlığ 1 verilerine göre 493.403 kişiye ikinci doz uygulanmıştır. (CNN Türk, 2020; T.C. Sağlık Bakanlığı, 2021b). Aşı 18 yaş altı kişilere, hamilelere ve son 6 ay içerisinde Covid-19 teşhisi almış kişilere uygulanmamaktadır. Aşı randevuları Merkezi Hekim Randevu Sistemi (MHRS) web sitesinden veya ALO 182'yi arayarak alınmaktadır (HaberTürk, 2021). Randevu alamayan yaşlıların aşı takvimi ve randevuları aile hekimlikleri tarafından düzenlenmektedir. Aşı için sağlık tesisine gidemeyen kişilerin aşıları evde sağlık hizmeti birimleri tarafından yapılmakta olup huzurevi ve bakımevinde kalanlar kurumlarında; 90 yaş ve üstü bireyler ise evlerinde aşılanmışlardır (Anadolu Ajansı, 2021). Salgının tıbbi boyutunda aşılamaya büyük önem verilmiştir. Ancak Türkiye'de Covid-19 aşısı diğer aşılarda olduğu gibi zorunlu değildir. Toplumdaki nüfus gruplarında Covid-19 bulaş riski en fazla olan yaşlllar için de bir zorunluluk söz konusu değildir.

Sağlık, psiko-sosyal ve ekonomik açılardan dezavantajlı grup olarak yaşlılar, Covid-19 salgınının ilk günlerinden itibaren en çok gündeme gelen ve ele alınan gruplardan olmuşlardır. Salgın süresince yaşlılara sunulan hizmetlerin geliştirilmesi ve yaşlılara sunulan hizmetlerin çeşitlendirilmesi noktalarında, ekonomik boyutta destek sağlanması boyutunda, kısıtlamalar ve izinler ile ilgili birçok çalışma yapılmıştır.

\section{Sonuç ve Öneriler}

Covid-19 salgını en temelde bir hastalık olmasının ötesinde bireyleri, aileleri ve toplumları biyolojik, psikolojik, sosyal ve ekonomik yönden etkileyen küresel bir afettir. Salgın ortaya çıttğı günden bu zaman kadar dünya genelinde milyonları hasta etmiş ve milyarları eve hapsetmiş̧ir. Enfekte olanların çoğu hastalığı hafif şekilde atlatsa da dezavantajlı gruplar arasında bulunan yaşlılar için aynı şeyi söylemek mümkün değildir.

Yaşlanma kaçınılmaz bir süreçtir. Her gelişim evresinde olduğu gibi yaşlılık döneminin de kendine has sorunları mevcuttur. İnsanlar yaşlandıkça sağlık sorunları da beraberinde artma eğiliminde olur. Yaşlılık döneminde 
kardiyovasküler hastalıklar, nörolojik hastalıklar, sindirim ve solunum sistemi rahatsızlıkları ve enfeksiyonlar önemli sağlık sorunları arasında sayılabilir. Yaşlanmayla birlikte birey rol, statü ve sosyal işlevselliklerinde kayılpları yaşayabilmektedir. Dahası salgın döneminde yaşlı bireyler depresyon, anksiyete, stres, umutsuzluk, yalnızlık ve ölüm korkusu gibi psikolojik sorunlar yaşayabilmektedir. Aynı zamanda yine bu dönemde yaşılıar sosyal dışlanmaya, yaş ayrımcllı̆ına ve damgalanmaya maruz kalabilmektedir.

Yaşlılık döneminin kendine ait sorunlarına ek olarak yaşanan Covid-19 salgını yaşlıların yaşam kalitesini ve yaşam doyumlarını olumsuz yönde etkilemiştir. Süreç içinde yaşlılara yönelik yasaklar, kısıtlamalar ve önlemler ilk başlarda hem sosyal hayatta hem de sosyal medya ortamlarında bir eğlence unsuru olarak görünse de aslında yaş ayrımcllı̆ıının somut göstergeleri olarak karşımıza çıkmaktadır. Öte yandan bu dönemde yaşlıların izole olmasından ve hastalığın belirsizliğinden kaynaklı olarak depresyon, anksiyete, stres, korku, öfke, ajitasyon, yalnızlık ve değersizlik duygusu yaşamaktadırlar.

Covid-19 salgınına yönelik vakaların Türkiye'de görüldüğü ilk günden itibaren ülke ve tüm toplum olarak salgına yönelik bir hazırlık süreci başlatılmıştır. Salgının Türkiye öncesinde birçok dünya ülkesinde görülmüş olması, yıkıcı etkilerinin öncesinden bilinmesi ve diğer ülkelerin bu konuda yürüttükleri çalışmalar Türkiye açısından bir ön deneyim ve hazırlık niteliği taşımıştır. Türkiye'de henüz vaka görülmeden salgına yönelik çalışmalar hız kazanmışır. Salgının ilk günlerinden itibaren sağlık hizmetleri başta olmak üzere birçok toplumsal düzenleme hayata geçirilmiştir. Toplumsal olarak koronavirüsün ağır sonuçlarla seyrettiği yaşlılara yönelik özel düzenlemeler düşünülmüş ve hayata geçirilmiştir. Bu çalışmada Türkiye' de yaşlllara yönelik hizmetler beş temel kategoride incelenmiştir. Bunlar yaşlılara sunulan hizmetler, kısitlamalar, ekonomik destek, tıbbi hizmetler, izin ve ayrıcalıklardır.

Genel olarak yaşlılara sunulan hizmetler boyutunda, birçok ülkenin aksine Türkiye salgın daha ülkeye giriş yapmadan yaşlılar ve diğer yaş grupları için önlemleri almaya başlamıştır. AÇSHB kendisine bağlı kurum ve kuruluşlarda Covid-19 önlemlerini 2020 Ocak ayı itibariyle oluşturmaya başlamıştır. İlk vakanın görüldüğü 11 Mart 2020 tarihinden sonra tedbirler ülke genelinde daha da arttırılmış ancak vaka sayılarındaki artış nedeniyle sokağa çıkma kısıtlamaları yapılmıştır. 65 yaş ve üstü ve kronik rahatsızlığı olan kişilerin Covid-19'un bulaşmasını engellemek için ikamet ettikleri yerden çıkmaları yasaklanmıştır. Bu grupta olan insanların gıda, su, temizlik gibi temel 
ihtiyaçlarını karşılamak için Vefa Sosyal Destek Grupları kurulmuştur. Huzurevleri ve bakım evlerinde 14 günlük vardiyalı çalışmaya geçilmiştir. Emekli maaşının en az 1500 TL'ye çıkarılması, bayramlarda emeklilere ödenen ikramiyelerin önceden ödenmesi ve beyanname süresinin uzatılması gibi birçok ekonomik destek gerçekleştirilmiştir. Bunların dışında sadece yaşlılar için değil nüfusun geneli için AÇSHB Covid-19 salgını sürecinde muhtaç ve ihtiyacı olan kişiler için 1000 TL sosyal yardım sağlamıştır.

Salgın sürecinde kurum bakımı dışında kalan ve kısıtlamaya tabi yaşlıların ihtiyaçların karşılanmasına yönelik özel hizmet gruplarının oluşturulması ve ekonomik anlamda yaşlılara destek sağlanması, salgın sürecinde olumlu bir etki yaratmış olsa da uzun süreli ve planlı hizmetlerin hayata geçirilmemiş olması bir eksikliklik olarak değerlendirilebilir. Türkiye, Covid-19 salg1nında kurum bakımındaki yaşlılara yönelik hizmetleri ve tedbirleri sistematik ve planlı bir şekilde yönetmiştir. Ancak, kurum bakımı dışında kalan ve profesyonel bakım hizmetlerinden yararlanmayan yaşlılar için hizmetler ve tedbirlerin uygulanabilirliği ve takibi tartısılması gereken konulardandır.

Sonuç olarak, Covid-19 salgını bilinmezlikler ile başlayan belki de bu yüzyıla damgasına vuracak önemli olaylardan birisidir. Salgının ilk zamanlarında Çin'den gelen verilerde ölümlerin çoğunun (\%80) yaşlılarda olması birçok toplumda farklı tepkilere neden olmuştur. Bireyselliğin ve ayrımcılığın ön planda olduğu bazı çok küçük toplumlarda, yaşlılara yönelik olumsuz fikirler ortaya atılmış olsa da genel anlamda yaşlılar tüm dünyada özel korunması gereken grup olarak tanımlanmış ve salgında özellikle yaşlıların korunmasına yönelik birçok hizmet sunulmuştur. Bu bağlamda, sürecin başından itibaren Türkiye hiçbir ayrım gözetmeksizin insanın onur ve değerine uygun olarak hem özelde yaşlılara yönelik hem de genel nüfusa yönelik geliştirdiği uygulamalar ile örnek gösterilen bir ülke olmuştur. Türkiye'nin salgını yönetmedeki deneyimi ileride yaşanabilecek salgınlar konusunda ülkenin daha hazırlıklı olmasına katkı sağlayacaktır.

Türkiye'nin Covid-19 salgın sürecinde yaşlllara yönelik hizmetler konusunda genel bir başarıdan söz ederken, sunulan hizmetlerin planlı ve programlı olması, profesyonel hizmetlerin yaygınlaştırılması, hizmetlerin yerindeliği, çeşitliliği, ihtiyaçları karşılamada yeterliği gibi konularda geliştirilmesi gereken yönleri olduğu düşünülmektedir. Bu bağlamda, yaşlılara yönelik hizmetlerin geliştirilmesine yönelik öneriler oluşturulmuştur. 


\section{Hizmetler boyutunda öneriler}

Salgın süresince yaşlılara yönelik hizmetler boyutunda genel bir başarıdan bahsedilmekte ancak sunulan hizmetlerin niteliği, niceliği ve sürekliliği boyutunda geliştirilmesi gerekmektedir.

Covid-19 salgını dünya genelinde her alanda bir dijitalleşme ortaya çıkarmıştır. Bu bağlamda teknoloji ve internet kullanımının artması ile kişilerin bilgiye ve hizmetlere erişimi teknoloji ve bilişim konularında yetkin olmaları ile bağlantılandırılmıştır. Türkiye' de yaşlıların büyük kesimini teknolojiyi ve interneti kullanmada hatta mobil telefonları bile kullanmada sorun yaşadıkları düşünüldüğünde, yaşlılara dijitalleşme, teknoloji ve internet kullanımı hakkında eğitimler verilmesi gerekmektedir.

Teknoloji kullanımı ile yaşlıların sağlık sorunlarının yanında psiko-sosyal açıdan da tam bir iyilik halini sağlamak için ücretsiz internet ve erişim hizmeti sağlanmalıdır. Buna bağlı olarak yaşlıların güncel kitle iletişim araçlarını kullanmaları ve iletişim ihtiyaçlarını azami düzeyde karşılamaları için akıllı telefon ve tablet bilgisayarlar gibi teknolojik ürünlerle desteklenebilir.

Yaşlıların, gelişim dönemlerinde yaşadığı en büyük sorunlar olarak yalnızlık, umutsuzluk ve çaresizlik gibi duyguların salgın ile daha da artış göstereceği ve yaşlıların ruhsal ve psikolojik durumlarını kontrol altında tutmak ve iyileştirmek için mobil psiko-sosyal destek servisleri ve numaraları hizmete alınmalıdır.

Salgın durumlarında yaşlıların da sağlığını tehlikeye atmamak koşuluyla, özellikle yalnız yaşayan yaşlılara profesyonel ekiplerce ziyaretler gerçekleştirilmeli ve yaşlılara yönelik durum raporu hazırlanmalıdır.

Yaşlıların normal yaşamlarında boş zaman değerlendirme faaliyetlerinin yerine alternatif olabilecek hizmetlerin yapılandırılması, geliştirilmesi ve hizmete sunulması hem yaşlıların ruh sağlığı hem de psiko-sosyal sağlıkları açısindan önemli bir yere sahiptir.

Türkiye'de salgın hastalıklar için oluşturulmuş bir acil durum ve salgın eylem planının eksikliğine bağlı olarak kriz müdahalelerinde aksamalar yaşanmaktadır. Bu bağlamda Türkiye'de daha profesyonel ve yapılandırılmış kriz müdahalelerine ihtiyaç duyulmaktadır. Covid-19 salgını ile tüm toplumu kapsayacak şekilde salgınların ekonomik, sosyal ve psikolojik boyutlarını göz önünde bulundurmalı ve sosyal hizmet uzmanı, psikolog, sosyolog, 
ekonomist ve psikolojik danışmanlardan oluşan multidisipliner bir kriz müdahale ekibinin ya da bu alanları da kapsayan bilim kurullarının oluşturulması gerekmektedir.

Salgın dönemlerinde, salgının ekonomik ve psiko-sosyal etkilerinin önüne geçebilmek adına AFAD, Kızılay gibi kurum ve kuruluşlarla birlikte sivil toplum örgütlerine de yetki verilmeli ve buna bağlı olarak koruyucu ve önleyici tedbirler düşünülmelidir.

Salgın dönemlerinde en fazla riskli gruplardan olan yalnız yaşayan yaşl1ların ilgili birimlerde görevli sosyal hizmet uzmanları tarafından takibi sağlanmalı ve sosyal hizmetin vaka yönetici rolünden faydalanılmalıdır.

Salgın bağlamında yaşlılara sunulan hizmetlerin kapsayıcı olması; kurum bakımı altında olan ve olmayanlar için hizmetlerin çeşitlendirilerek niteliğinin arttırılması dahası verilen bu hizmetlerin takibinin yapılması gerekmektedir.

\section{Kisitlamalar boyutunda öneriler}

Yaşlılara yönelik kısıtlamaların kapsayıcı olması ve yaşlılık dönemine özel durumların göz önünde bulundurularak gerçekleştirilmesi gerekmektedir. Yaşlılık döneminde hareketli ve aktif olmanın yaşlıların sağlıklı bir dönem yaşamalarında etkili olduğu unutulmamalı ve kısıtlamaların yaşlıların aktif günlük hareketlerini kısıtlamayacak şekilde düzenlenmesi gerekmektedir. Yaşlılık döneminde yaşlıların aile ve sosyal destek sistemlerinin yaşlı ruh sağlığı üzerinde olumlu etkisi düşünülerek, kısıtlamaların sosyal destek sistemlerini engellememesi sağlanmalıdır. Bu süreçte yalnız yaşayan yaşlıların tıbbi ve psiko-sosyal takibi için çevrimiçi görüşmeler gerçekleştirilmelidir. Bu bağlamda yalnız yaşayan yaşlıların tespiti ile ikametlerinde uzaktan kontrollerin sağlanabilmesi için gerekli teknolojik altyapının oluşturulması sağlanmalıdır.

Kurum bakımı alan yaşlılarda kısıtlamaların fiziksel ve psiko-sosyal izolasyona dönüşmeden hayata geçirilmesi için araştırmalar yapılmalı ve yeni modeller üzerinde çalışılmalıdır.

\section{Ekonomik destek boyutunda öneriler}

Ekonomik sorunlar yaşlılık dönemi sorunlarının başında gelmektedir. Salgın durumlarında yaşlıların ekonomik yönden desteklenmesi, diğer sorunların 
ortaya çıkmasını engellemek ve yaşlıların süreçten en az düzeyde etkilenmelerini sağlamaktadır. Bu bağlamda Türkiye'de Covid-19 salgını ile yaşlılara ekonomik destek boyutunda destekler sunulmuş olsa da desteklerin niteliği ve niceliği artırılmalı ve destek miktarları artırılarak kalıcı hale getirilmelidir. Salgın dönemlerinde yaşlılar artan enflasyon ve harcamalara karşı korunmalı, buna bağlı olarak yaşlılar ve engelliler gibi dezavantajlı grupların temel ihtiyaçları, sağlık ve ilaç harcamaları gibi alanlarda kullanılmak üzere fonlar oluşturulmalıdır.

Yaşlı ve engelli gibi bütün dezavantajlı gruplar salgın dönemleri için tanımlanarak, sosyal devlet ilkesi gereği bakım ve desteklenmesi devlet tarafindan garanti altına alınmalıdır.

Salgın dönemlerinde, yaşlılar için faizsiz kredi kredilerinin ve faturalarının ertelenmesi gibi destekler artırılmalı ve yaşlılar için ulaşılabilir ekonomik imkanlar sunulmalıdır.

\section{İinler ve ayricaliklar}

Covid-19 salgını ile yaşlılar daha çok kısıtlamalar ile anılsa da yaşlıların sağlık ve psikolojik durumları da düşünülerek ayrıcalıklar ve izinler konusu da gündeme gelmiştir. Yaşlıların belirli saat aralığında sokağa çıkmasına izin verilmiş olsa da yaşlıların bedensel ve ruhsal sağlı̆̆ını korumak için izinler yetersiz kalmıştır. Yaşlılara sunulan izinlerin ve ayrıcalıkların, kırsal ve kentsel farklılıkları ve imkanları düşünerek planlanması daha uygun olacaktır.

Yaşlılara yönelik gerek sosyal medyada gerekse ulusal basında çıkan aşağılayıcı, onur kırıcı, değersizleştiren söylemlerin engellenmesi, yaşlı ayrımc1lığını önleyici, toplumsal bütünleşme ve kaynaşma için çalışmalar yapılması gerekmektedir.

Kurum bakımı alan yaşlıların iyilik hali gözetilerek yakınları ile görüşmeleri ve ziyaretler düzenlenmeli, fiziksel olarak görüşmelerin sağlanması için uygun şartların oluşmaması durumunda sanal görüşmeler planlanmalı ve organize edilmelidir.

\section{Tıbbi hizmetler boyutunda öneriler}

Sadece yaşlılara yönelik değil bütün nüfusa yönelik uygulanan tele-tıp uygulamalarının Covid-19 bulaşma riski azalttı̆̆1 söylenebilir. Covid-19 salgını 
tele-tıp uygulamalarını artırmış olsa da salgın sonrası dönemde de kullanılması insanların konforlarını arttıran bir uygulama olacaktır. Bu nedenle teletıp uygulamaları geliştirilmeli ve yaygınlığı arttırılmalıdır.

Covid-19 salgınında yaşlılar için diğer önemli boyut olan aşılamada Türkiye hızlı yol kat edilmiştir. Aşılama ile ilgili bazı aksaklıklar da bulunmaktadır. Covid-19'u geçiren kişilere aşı yapılmaması ve aşı yapılan yaşlıların sokağa çıkma yasağının devam ediyor olması bu aksaklıklar içinde sayılabilir. Dahası aşı yapılmasını reddeden yaşlıların daha sonra sokağa çıkma yasağının devam edip etmeyeceği de merak konusudur. Bu bağlamda Covid-19 salgınında en büyük risk grubunu oluşturan yaşlılar için tamamen isteğe bağlı olan aşılamanın aksine, aşılanmanın özendirilmesine yönelik çalışmalar yapilması gerekmektedir. 


\title{
EXTENDED ABSTRACT
}

\section{Evaluation of Applications and Services for the Elderly During the Covid-19 Outbreak in Turkey}

\author{
Aykut Can Demirel - Semih Sütçü \\ Muğla Sıtkı Koçman University, Recep Tayyip Erdoğan University
}

Since its existence on Earth, humanity has faced many disasters, such as war, migration and shortage, and these disasters have profoundly affected people's lives. One of the disasters that leave deep traces on humanity and force change and transformation of humanity is outbreaks. Throughout history, humanity has witnessed many outbreaks such as plague, cholera, influenza, and tuberculosis at a regional or global level. These outbreaks have affected the course of history and the development of humanity, moreover, they have caused trauma to individuals and societies by causing many people to die. One of these outbreaks is Covid-19.

The Covid-19 outbreak has affected the whole world psychologically, socially, and economically. Although almost all population groups of societies were affected in the outbreak, people over a certain age had more severe disease or lost their lives due to this disease pandemic. The fact that the Covid19 outbreak caused the most deaths in the elderly, both in Turkey and in many countries, has provided an environment for measures, restrictions and bans specific to the elderly, as well as the birth of new service models.

The fight against the Covid-19 outbreak, especially the work on the elderly, is important for preparing and responding to future outbreaks. For these reasons, the main aim of the study was to examine and evaluate the practices and services for the elderly in Turkey during the Covid-19 outbreak.

Applications and services for the elderly in the Covid-19 outbreak in Turkey can be evaluated in five different categories. These categories; the first risk group for the isolation of the elderly as "restrictions", the second, depending on the restrictions offered "services", the third with the outbreak, with the increase of expenditures for both health and basic needs, "economic 
assistance" and the fourth elder of the physiological, psychological, emotional and social needs, "the permissions and privileges" for the latter treatment and vaccines, and "medical services" can be listed.

Services for the elderly: Depending on the course of the outbreak in Turkey, practices aimed at the elderly population have also been implemented, as well as practices that cover the entire community. First, a "follow-up and Monitoring Unit" was created to combat the outbreak quickly and effectively. Accordingly, the "Coronavirus Scientific Advisory Board" was established by the Ministry of Health of Turkey. Subsequently, guidelines containing specific standards and rules for Aged Care and nursing homes have been prepared. These guidelines describe measures for Aged Care and nursing homes. In this context, administrative measures, measures for service areas and measures for employees are explained in detail. Regional "Vefa Social Support Groups" have been established by the Ministry of Interior of Turkey to meet the needs of elderly people living in their own homes. The Vefa Social Support Groups consist of public employees such as police, gendarm, watchmen, teachers, as well as volunteers.

Restrictions on the elderly: Because the elderly are the largest risk group in the Covid-19 outbreak, the elderly are prohibited from leaving their homes, wandering in open spaces, parks, and traveling by public transportation.

Economic support services for the elderly: In addition to services such as making pension payments to the elderly at their residence and delaying tax payments, the base pension has been raised with the idea that the outbreak will increase economic problems.

Permissions and privileges for the elderly: Many of the privileges imposed at the first stage for the elderly were treated as conditional privileges. Due to the emergence of many health problems and psycho-social problems with inactivity and decreased activity in old age, they could go out in a certain period of time later in the outbreak.

Medical services for the elderly: In the covid-19 outbreak, the most effective use of medical services for the elderly in Turkey was tried. It is possible to 
assess these medical services for the elderly in two dimensions. The first of these is tele-medicine applications and the second is vaccination studies.

During the Covid-19 outbreak, live physician interviews, medical analyses' results, radiology results were provided, and diet lists were organized within the scope of tele-medicine practices to elderly by medical staff in Turkey. Tele-medicine practices were informed about the Covid-19 outbreak, and in addition, the requirement for prescribing reported drugs for those with chronic conditions was abolished. Vaccination of the population in Turkey was planned to be carried out in 4 stages within a program. In the first stage, along with health care staff, elderly people, disabled and those living at nursing homes were vaccinated.

Since the first day of the cases of the Covid-19 outbreak in Turkey, a preparation process for the outbreak has been initiated as a country and as a whole society. Covid-19 the spread of the outbreak in many countries before Turkey, the devastating effects of the disease were known before and the struggle of these countries for the outbreak was a preliminary experience and preparation from the point of view of Turkey. Before the case was seen in Turkey, studies on the outbreak gained momentum. Since the first days of the outbreak, many social regulations, especially health services , have been implemented. In society, special arrangements for the elderly, where coronavirus is observed with severe consequences, have been considered and implemented. In this study, services for the elderly in Turkey were examined in five main categories. These are restrictions, economic support, medical services, permits and privileges available to the elderly.

The establishment of special service groups to meet the needs of the elderly who are excluded from institutional care and who are subject to restriction during the outbreak process and providing support to the elderly in economic terms has had a positive effect on them during the outbreak process. But the fact that long-term and planned services have not been implemented can be considered a lack of struggle. It can be said that the services and measures developed by Turkey for the elderly in the care of institutions were successful in the Covid-19 outbreak process. However, the applicability and follow-up of services and measures for elderly people who are out of the institutional care and do not benefit from professional care services are among the issues that need to be discussed. 
Another disadvantage in the Covid-19 outbreak is that studies involving the personnel who will perform these services and practices have not been conducted. Although working with the elderly is a challenging and debilitating situation, the extraordinary circumstances created by the Covid-19 outbreak have brought more responsibility to people working with the elderly. Especially during the Covid-19 process, the staff working in nursing homes had to work in the institution for 14 days, which may have caused these staff to experience psychosocial problems. These problems may have caused other problems in both personal and business lives of people working in the field of elderly people care. For this reason, the needs and expectations of the staff who will serve the elderly should also be considered when planning services and practices for the elderly.

As a result, the Covid-19 outbreak is perhaps one of the important events that will mark this century. The fact that most of the deaths $(80 \%)$ in data from China in the early days of the outbreak were in the elderly caused different reactions in many communities. Unfortunately, this situation has led to discriminatory and stigmatizing movement against older people, especially on social media. Fortunately, states have taken the necessary measures on this issue and identified the elderly as a special group that needs to be protected all over the world. In this way, many services and applications have been developed, especially for the protection of the elderly people. In this context, from the beginning of the process, Turkey has been an exemplary country with its practices developed both specifically for the elderly and for the general population in accordance with the dignity and value of the human being without any discrimination. Turkey's experience in managing an outbreak will contribute to its better preparation for future outbreaks.

In the Covid-19 outbreak process of Turkey, there can be a general success in services for the elderly, but it is believed that the services offered are planned and programmed, the dissemination of professional services, the availability of services, diversity, competence in meeting needs.

\section{Kaynakça / References}

AÇSHB. (2020a). Kuruluşlarımıza yönelik koranavirüs bilgilendirme rehberi II. Ankara: AÇSHB.

AÇSHB. (2020b). 65 yaş üzeri yaşllar ve kronik hastallğı bulunan yaşllara yönelik koranavirüs bilgilendirme rehberi IV. Ankara: AÇSHB. 
AÇSHB. (2020c). Kuruluşlarımıza Yönelik Covid-19 Normalleşme Rehberi - I. Ankara: AÇSHB.

Yurt genelindeki 90 yaş ve üstü evlerinde aşılanıyor. (2021). Anadolu Ajansı. 13.02.2021 tarihinde https:/www.aa.com.tr/tr/koronavirus/yurt-genelindeki-90-yasve-ustu-evlerinde-asilaniyor/2115421 adresinden alındı.

Sağlık Bakanlığından diyaliz merkezlerine Kovid-19 Önerileri. (2020). Anadolu Ajansı. 14.02.2021 tarihinde .https://www.aa.com.tr/tr/koronavirus/saglik-bakanligindan-diyaliz-merkezlerine-kovid-19-onerileri-/1806871\# adresinden alindi.

Altın, Z. (2020). Covid-19 pandemisinde yaşlılar. Tepecik Eğitim ve Araştırma Hastanesi Dergisi, 49-57. http://dx.doi.org/10.5222/terh.2020.93723

Aşkın, R., Bozkurt, Y. ve Zeybek, Z. (2020). Covid-19 pandemisi: Psikolojik etkileri ve terapötik müdahaleler. İstanbul Ticaret Üniversitesi Sosyal Bilimler Dergisi, 19(37), 304-318.

Koronavirüs: Türkiyenin Komşularında Covid-19 Salgını Ne Aşamada, Sınır Kapılarinda Son Durum Ne? (2020). BBC. 19.03.2021 tarihinde https://www.bbc.com/turkce/haberler-turkiye-53018231 adresinden alınd1.

Buz, S. (2015). Yaşlı bireylere yönelik yaş ayrımcllı̆̆ı. Elektronik Sosyal Bilimler Dergisi, 14(53), 268 - 278. http://dx.doi.org/10.17755/esosder.89453.

Charumilind, S., Craven, M., Lamb, J., Sabow, A. ve Wilson, M. (2020). When will the Covid-19 pandemic end? 01.01.2021 tarihinde https://www.mckinsey.com/industries/healthcare-systems-and-services/our-insights/when-will-the-covid-19-pandemic-end\#: :text=The\%20positive $\% 20$ readouts $\% 20$ from $\% 20$ the, in $\% 20 \mathrm{Q} 3 \% 20$ or $\% 20 \mathrm{Q} 4 \% 202021$. adresinden alınd.

Chen, Q., Liang, M., Li, Y., Guo, J., Fei, D., Wang, L., . . Li, X. (2020). Mental health care for medical staff in China during the COVID-19 outbreak. The Lancet Psychiatry, 7(4), e15-e16. http://dx.doi.org/10.1016/S2215-0366(20)30078-X

Son Dakika: Erdoğan'dan aşı açklaması: Önümüzdeki ay başlıyor. (2020). CNN Türk. 14.02.2021 tarihinde https:/www.cnnturk.com/turkiye/erdogandan-asiaciklamasi-onumuzdeki-ay-basliyor adresinden alınd.

Çapacı, M. ve Özkaya, S. (2020). COVID-19 pandemi döneminde tele-tıp uygulamaları. Anadolu Kliniği Tip Bilimleri Dergisi, 25(1), 260-262. http://dx.doi.org/10.21673/anadoluklin.738672

Danış, Z. ve Günay, G. (2019). Yaşlılık döneminde karşılaşılan psikososyal sorunlar. U. Yanardağ ve M. Zubaroğlu Yanardağ, Yaşlılık ve Sosyal Hizmet içinde (s. 43-66). Ankara: Nobel Akademi Yayınları. 
Dubey, S., Biswas, P., Ghosh, R., Chatterjee, S., Dubey, M. J., Chatterjee, S., . . Lavie, C. J. (2020). Psychosocial impact of COVID-19. Diabetes \& Metabolic Syndrome: $\begin{array}{lllll}\text { Clinical Research } \mathcal{E} \quad \text { Reviews, 14(5), } & \text { 779-788. }\end{array}$ http://dx.doi.org/10.1016/j.dsx.2020.05.035

Duran, Y. (2021). Pandemi günlerinde dayanışmanın çarpan etkisi: Vefa sosyal destek grubu. 15.02.2021 tarihinde https://yesilay.org.tr/tr/makaleler/pandemi-gunlerindedayanismanin-carpan-etkisi-vefa-sosyal-destek-grubu adresinden alındı.

Durmuş, S. ve Şahin, D. (2020). Covid-19 küresel salginda Dünyada ve Türkiye'de uygulanan ekonomi politikaları üzerine bir değerlendirme. Turkish Studies, 15(4), 923-943. http://dx.doi.org/10.7827/TurkishStudies.44506

Dylan, K. (2012). Is social exclusion still important for older people? London: The International Longevity Centre.

Ekici, E. (2020). Covid 19 pandemisi sürecinde yaşılı bireylerin bakım yönetimi. Haliç Üniversitesi Sağllk Bilimleri Dergisi, 3(3), 145-152.

Engelli ve Yaşlı Hizmetleri Genel Müdürlüğü. (2020). 65 yaş üzeri yaşllar ve kronik hastalı̆̆ı bulunan yaşllara yönelik koronavirüs (covid-19) bilgilendirme rehberi - VI. Ankara: T.C. Aile Çalışma ve Sosyal Hizmetler Bakanlığı.

Erdem, İ. (2020). Koronavirüse (Covid-19) karşı Türkiye'nin karantina ve tedbir politikaları. Turkish Studies, 15(4), 377-388. http://dx.doi.org/10.7827/TurkishStudies. 43703

Dünyada covid-19: Ilk 4 ayında neler yaşandı? Salgının seyri ne durumda? (2020). Euronews. 30.12.2020 tarihinde https://tr.euronews.com/2020/05/04/dunyada-covid-19-salg-n-n-ilk-100-gununde-yasananlar-ilk-nerede-ortaya-c-ktnas-l-yay-ld adresinden alınd.

Gencer, N. (2020). Kovid-19 sürecinde yaşlı olmak: 65 yaş ve üstü vatandaşlar için uygulanan sokağa çıkma yasağı üzerine değerlendirmeler ve manevi sosyal hizmet. Türkiye Sosyal Hizmet Araşttrmalan Dergisi, 4(1), 35-42.

Genç, Y. ve Barış, İ. (2015). Yaşlı bakım merkezlerinde çağdaş yaklaşım: Kurumsal bakım yerine evde bakım hizmetlerinin güçlendirilmesi. Akademik Sosyal Araşttrmalar Dergisi, 3(10), 36-57. http://dx.doi.org/10.16992/ASOS.507

Göksu, Ö ve Kumcağız, H. (2020). Covid-19 salgınında bireylerde algılanan stres düzeyi ve kaygi düzeyleri. Turkish Studies, 15(4), 463-479. http://dx.doi.org/10.7827/TurkishStudies.44397

Halk Sağlığı Genel Müdürlüğü. (2020a). Covid-19 (yeni koronavirüs hastalı̆̆l) nedir? 01.01.2021 tarihinde https://sagligim.gov.tr/yeni-2019-n-cov-virus-koronavirus.html adresinden alındi. 
Halk Sağlığı Genel Müdürlüğü. (2020b). Covid-19 (sars-cov-2- enfeksiyonu bilim kurulu çalışması) enfeksiyon kontrolü ve izalasyon. Ankara: T.C. Sağlık Bakanlığı Halk Sağlı̆ğ Genel Müdürlüğü.

Huang, C., Wang, Y., Li, X., Ren, L., Zhao, J., Hu, Y., .. Cao, B. (2020). Clinical features of patients infected with 2019 novel coronavirus in Wuhan, China. The Lancet, 395, 497. http://dx.doi.org/10.1016/S0140-6736(20)30183-5

1 Temmuz'da (bugün) nereler açıldı? İşte normalleşme takviminde 1 Temmuz'da açllan yerlerin listesi. (2020a). Hürriyet Gazetesi.30.12.2021 tarihinde https://www.hurriyet.com.tr/galeri-1-temmuzda-bugun-nereler-acildi-isteicisleri-bakanligi-genelgesine-gore-bugun-acilan-yerlerin-listesi-41554111/7 adresinden alındı.

Koronavirüs aşısı ilk kimlere, ne zaman yapılacak? Bakan Koca Bilim Kurulu Toplantısı sonrası açıkladı. (2020b). Hürriyet Gazetesi. 03.01.2021 tarihinde https://www.hurriyet.com.tr/gundem/son-dakika-haberi-koronavirusasisi-ilk-kimlere-ne-zaman-yapilacak-bakan-koca-bilim-kurulu-toplantisisonrasi-acikladi-41678316 adresinden alındı.

İnce, C. (2020). Afetlerde sosyal savunmasız bir grup olarak yaşlllar: Covid-19 örneği. Avrasya Sosyal ve Ekonomi Araştırmalan Dergisi (ASEAD), 7(9), 184-198.

Kalınkara, V. (2014). Temel gerontoloji yaşlllk bilimi. Ankara: Nobel Akademik Yayıncllik.

Karataş, Z. (2020). Covid-19 pandemisinin toplumsal etkileri, değişim ve güçlenme. Türkiye Sosyal Hizmet Araştırmalarn Dergisi, 4(1), 3-17.

Kourkouta, L., Iliadis, C. ve Monios, A. (2015). Psychosocial issues in elderly. Progress Health Sciences, 5(1), 232-237.

Lamprini, K. (2016). Social exclusion of elderly. Journal of Healthcare Communications, 1(3), 1-3. http://dx.doi.org/10.4172/2472-1654.100021

Lusardi, A. ve Mitchell, S. (2011). Financial literacy around the world: an overview. Journal of Pension Economics ve Finance, 10(4), 497-508. http://dx.doi.org/10.1017/S1474747211000448

Aşı randevu e-devlet ve MHRS ekranı: Koronavirüs aşı randevusu nasıl alınır? Adım adım aşı randevu alma. (2021). HaberTürk.14.02.2021 tarihinde https://www.haberturk.com/asi-randevu-e-devlet-ve-mhrs-ekrani-koronavirus-asi-randevusu-nasil-alinir-adim-adim-asi-randevu-alma-2965344 adresinden alınd.

Palmer, M. (2011). Disability and poverty: A conceptual review. Journal of Disability Policy Studies, 21(4), 210-218. http://dx.doi.org/10.1177/1044207310389333 
Parıldar, H. (2020). Tarihte bulaşıc hastalık salgınları. Tepecik Ĕ̆itim ve Araştırma Hastanesi Dergisi, 30, 19-26 http://dx.doi.org/10.5222/terh.2020.93764

Powell, A. (2020). Fauci says herd immunity possible by fall, 'normality' by end of 2021. 02.01.2021 tarihinde https://news.harvard.edu/gazette/story/2020/12/anthony-fauci-offers-a-timeline-for-ending-covid-19-pandemic adresinden alındi.

Reger, M. A., Stanley, I. H. ve Joiner, T. E. (2020). Suicide mortality and coronavirus disease 2019-a perfect storm? JAMA psychiatry, 77(11), 1093-1094. http://dx.doi.org/10.1001/jamapsychiatry.2020.1060

Reuters. (2021). WHO emergency Covid-19 vaccine listing aims to lift access in poor countries. https://www.reuters.com/article/us-health-coronavirus-vaccine-whoidUSKBN2951SG adresinden alındı.

Saladino, V., Algeri, D. ve Auriemma, V. (2020). The psychological and social impact of Covid-19: new perspectives of well-being. Frontiers in psychology, 11, 2550. http://dx.doi.org/10.3389/fpsyg.2020.577684

Santini, Z., Jose, P., Cornwell, E., Koyanagi, A., Nielsen, L., Hinrichsen, C., . . Koushede, V. (2020). Social disconnectedness, perceived isolation, and symptoms of depression and anxiety among older Americans (NSHAP): a longitudinal mediation analysis. The Lancet Public. http://dx.doi.org/10.1016/S24682667(19)30230-0

Sattari, S. ve Billore, S. (2020). Bring it on Covid-19: being an older person in developing countries during a pandemic. Working with Older People, 24(4), 281-291. http://dx.doi.org/10.1108/WWOP-06-2020-0030

Sepúlveda-Loyola, W., Rodríguez-Sánchez, I., Pérez-Rodríguez, P., Ganz, F., Torralba, R., Oliveira, D. ve Rodríguez-Mañas, L. (2020). Impact of social 1solation due to covid-19 on health in older people: Mental and physical effects and recommendations. The Journal of Nutrition, Health and Aging, PMC7514226, 1-10. http://dx.doi.org/10.1007/s12603-020-1469-2

Soysal, G. (2020). Koronavirüs salgını ve yaşlılık. Avrasya Sosyal ve Ekonomi Araştırmalarn Dergisi (ASEAD), 7(5), 290-301.

Sütçü, S. ve Demirel, A. C. (2020). Yaşlılık ve yaşlı sorunları. N. Çalış, ve Z. Karataş, Kavramsal ve Güncel Boyutlarryla Sosyal Sorunlar içinde (s. 167-199). İstanbul: Efe Akademi.

Şentürk, Ü. (2018). Yaşlılık sosyolojisi, yaşlılığın toplumsal yörüngeleri. Bursa. Dora Yayıncilik. 
Tamer, M. G. (2020). Korona salgınının (covid-19) toplumsal etkileri üzerine bir çalışma. Birinci Uluslararası Sosyal ve Beşeri Bilimler Araştırmaları Sempozyumu (USBBAS) Bilgitoy Tebliğler Kitabı (s. 1-15). Trabzon: Karadeniz Teknik Üniversitesi, Edebiyat Fakültesi.

Tanrıverdi, Ö. (2020). Covid pandemisi ve teletıp. Ş. Yalçn ve A. Özet, Kanser ve Covid-19 Pandemisi içinde (s. 211-218). Ankara: Türkiye Klinikleri.

T.C. İçişleri Bakanlığı. (2020a). 65 yaş ve üstü ile kronik rahatsızlı̆̆ı olanlara sokă̆a çıma yasağı genelgesi. 03.01.2021 tarihinde https://www.icisleri.gov.tr/65-yas-veustu-ile-kronik-rahatsizligi-olanlara-sokaga-cikma-yasagi-genelgesi\# adresinden alındı.

T.C. İçişleri Bakanlığı. (2020b). 65 yaş ve üzeri/20 yaş altı/kronik rahatsızlığı bulunan kişilerin sokă̆a çıkma kısıtlaması istisnası genelgesi. 03.01.2021 tarihinde https://www.icisleri.gov.tr/65-yas-ve-uzeri20-yas-altikronik-rahatsizligi-bulunan-kisilerin-sokaga-cikma-kisitlamasi-istisnasi-genelgesi adresinden alınd1.

T.C. İçişleri Bakanlığı. (2020c). Vefa sosyal destek grupları 6.649 .461 haneye ulaştı. 03.01.2021 tarihinde https://www.icisleri.gov.tr/vefa-sosyal-destek-gruplari-6649461-haneye-ulasti adresinden alınd.

T.C. İçişleri Bakanlığı. (2020d). Koronavirüs ile mücadele kapsamında - yeni kısıtlama ve tedbirler genelgeleri. 03.01.2021 tarihinde https://www.icisleri.gov.tr/koronavirus-ile-mucadele-kapsaminda-sokaga-cikma-kisitlamalari---yeni-kisitlamave-tedbirler-genelgeleri adresinden alınd.

T.C. Sağlık Bakanlığı. (2020a). Pandemi. 29.12.2020 tarihinde https://covid19.saglik.gov.tr/TR-66494/pandemi.html\#: :text=A\%C3\%A7\%C4\%B1klama $\% 3 \mathrm{~A} \% 20 \mathrm{COVID} \% 2 \mathrm{D} 19 \% 2 \mathrm{C}$ \%20\%C3\%BClkemizde,DS\%C3\%96) adresinden alındı.

T.C. Sağlık Bakanlığı. (2020b). Covid-19 haftalık durum raporu 12/10/2020 - 18/10/2020 Türkiye. Ankara: T.C. Sağlık Bakanlığı.

T.C. Sağlık Bakanlığı. (2020c). Covid-19 nedir?. 01.01.2021 tarihinde https://covid19.saglik.gov.tr/TR-66300/covid-19-nedir-.html adresinden alınd1.

T.C. Sağlık Bakanlığı. (2021a). İlk koronavirüs aşısı Sağlık Bakanı Fahrettin Koca'ya yapıldı. 13.02.2021 tarihinde https://www.saglik.gov.tr/TR,78148/ilk-koronavirusasisi-saglik-bakani-fahrettin-kocaya-yapildi.html adresinden alındı.

T.C. Sağlık Bakanlığı. (2021b). Covid-19 aşısı bilgilendirme platformu. 14.02.2021 tarihinde https://covid19asi.saglik.gov.tr/ adresinden alındı.

T.C. Sağlık Bakanlığı. (2021c). Türkiye covid-19 hasta tablosu 19 Mart 2021. 19.03.2021 tarihinde https://covid19.saglik.gov.tr/ adresinden alınd. 
Tatar, B. ve Adar, P. (2020). SARS-CoV-2: Mikrobiyoloji ve Epidemiyoloji. Tepecik Eğitim ve Araştrma Hastanesi Dergisi, 30, 27-35. http://dx.doi.org/10.5222/terh.2020.34392

Coronavirus Vaccine Tracker. (2020). The New York Times.02.01.2021 tarihinde https://www.nytimes.com/interactive/2020/science/coronavirus-vaccinetracker.html adresinden alınd.

65 yaş üzerindekilerin aşılanması yarın başlıyor. (2021). TRT Haber. 13.02.2021 tarihinde https://www.trthaber.com/haber/gundem/65-yas-uzerindekilerinasilanmasi-yarin-basliyor-555496.html adresinden alınd.

TÜIKK. (2020). İstatistiklerle yaşllar, 2019. 03.01.2021 tarihinde https://data.tuik.gov.tr/Bulten/Index?p=Istatistiklerle-Yaslilar-201933712\#: :text=Ya\%C5\%9Fl\%C4\%B1\%20n\%C3\%BCfus\%20son $\% 20 \mathrm{be} \%$ C5\% 9F\%20y\%C4\%B1lda\%20\%21\%2C9\%20artt $\%$ C4\%B1vetext=Ya\%C5\%9Fl\%C4\%B1\%20n\%C3\%BCfusun $\% 202019 \% 20 y \%$ C4 $\%$ B11\%C4\%B1nda $\% 20 \% 44, \% 25 \% 2$ C6\%20olaca $\%$ C4 $\% 9$ adresinden alınd.

Türk, A. (2020). Koronavirüs (Covid-19) pandemisi sürecinde yaşllara yönelik uygulamalar ve yaşlıların psiko-sosyal durumu üzerine bir değerlendirme. Sosyal Hizmet "Social Work", 35-46.

UN News. (2020). World must be ready for the next pandemic, The UN says on first International Day of Epidemic Preparedness. 02.01.2021 tarihinde https://news.un.org/en/story/2020/12/1080922 adresinden alındı.

United Nations. (2019). Ageing. 03.01.2021 tarihinde https://www.un.org/en/sections/issues-depth/ageing/ adresinden alındı.

Uyanusta Küçük, Ç. (2020). Klinik perspektiften gelecekteki Tele-Tip uygulamalar1nın yaşlllık boyutu. Y. Gökçe Kutsal ve D. Aslan, Covid-19 Pandemi Sürecinde İleri Yaş Grubuna Yaklaşım içinde (s. 64-69). Ankara: Türk Geriatri Derneği.

Uysal, M. ve Eren, G. (2020). Covid-19 salgın sürecinde sosyal medyada yaşllara yönelik ayrımcllk: Twitter örneği. Turkish Studies, 15(4), 1147-1162. http://dx.doi.org/10.7827/TurkishStudies.44396

Vefikuluçay, D. (2008). Üniversitede öğrenim gören öğrencilerin yaşh ayrımchlı̆̆ına ilişkin tutumları. Doktora Tezi, Ankara: T.C. Hacettepe Üniversitesi Sağlık Bilimleri Enstitüsü .

Walsh, K., Scharf, T. ve Keating, N. (2017). Social exclusion of older persons: a scoping review and conceptual framework. European Journal of Ageing, 81-98. http://dx.doi.org/10.1007/s10433-016-0398-8 
Wang , H., Li, T., Barbarino, P., Gauthier , S., Brodaty , H., Molinuevo, J., ... , Yu, X. (2020). Dementia care during Covid-19. The Lancet, 395(10231), 1190-1191. http://dx.doi.org/10.1016/S0140-6736(20)30755-8

WHO. (2020a). Coronavirus disease (Covid-19). 01.01.2021 tarihinde https://www.who.int/emergencies/diseases/novel-coronavirus-2019/question-and-answers-hub/q-a-detail/coronavirus-disease-covid-19 adresinden alındı.

WHO. (2020b). Draft landscape of COVID-19 candidate vaccines. 30.12 .2020 tarihinde https://www.who.int/publications/m/item/draft-landscape-of-covid-19candidate-vaccines adresinden alınd.

WHO. (2021). WHO coronavirus disease (covtd-19) dashboard. 19.03.2021 tarihinde https://covid19.who.int/ adresinden alindi.

Yazar, E. (2020). Covid-19 pandemisinde kanserli hasta sağlığı ve tele sağlık uygulamaları. H. Gönderen Çakamak, Covid-19 Pandemisinde Telesağllk Uygulamalar içinde (s. 7-27). Ankara: IKKSAD Publishing House.

Zastrow, C. (2016). Sosyal hizmete giriş, 4. Baskı. (D. B. Çiftçi, Dü.) Ankara: Nika Yayınevi.

Zhou, P., Yang, X.-L., Wang, X.-G., Hu, B., Lei Zhang, L., Zhang, W., . . Shi, Z.-L. (2020). A pneumonia outbreak associated with a new coronavirus of probable bat origin. Nature Research, 579, 270-289. http://dx.doi.org/10.1038/s41586-020-2012-7

\section{Kaynakça Bilgisi / Citation Information}

Demirel, A. C. ve Sütçü, S. (2021). Covid-19 salgınında Türkiye'de yaşl1lara yönelik uygulamalar ve hizmetlerin değerlendirilmesi. OPUS-Uluslararası Toplum Araştırmaları Dergisi, 17(Pandemi Özel Say1s1), 3641-3675. DOI: 10.26466/opus.858337 